\title{
The Interplay and Feedback Mechanism between Environmental Pollution and Economic Growth in China
}

\author{
Zhaogang Wang ${ }^{1}$ \\ ${ }^{1}$ School of International Business Communications, Dongbei University of Finance and Economics, Dalian, \\ China \\ Correspondence: Zhaogang Wang, School of International Business Communications, Dongbei University of \\ Finance and Economics, Dalian, China. Tel: 86-139-4269-6559. E-mail: fromfrank@139.com
}

Received: July 13, 2012 Accepted: July 27, 2012 Online Published: August 20, 2012

doi:10.5539/eer.v2n2p53 URL: http://dx.doi.org/10.5539/eer.v2n2p53

\begin{abstract}
China's rapid economic growth has given rise to serious clashes with environment protection needs. In order to address the dilemma between environment protection and economic growth, a thorough investigation into the relationship between the two is fundamental to the formulation and implementation of environment policies. This paper uses econometric analyses of time-series data on industrial pollution and GDP per capita between 1980 and 2008, examines the long-term dynamic equilibrium and interplay between environment quality and per capita income in China, and obtains the following points. First, there is cointegration between economic growth and environment pollution in China. Second, the increase of per capita GDP has evident lag effects on environment quality. Third, the simulated structure of Generalized Impulse Response Function shows that the responses of environment quality indicators to the impulse of per capita growth rate are mostly fluctuant. Fourth, the results of variance decomposition show that the contribution of pollution indicators to the variance decomposition of GDP per capita is relatively small.
\end{abstract}

Keywords: economic growth, environment pollution

\section{Introduction}

The cumulative effects of environment pollution on climate change and ecological deterioration are growingly prominent. As such, more scientists and professionals are exploring the relationship between economic growth and environment pollution empirically. On the one hand, the development of pertinent theories calls for the corresponding empirical tests for support; on the other hand, there have been better data on environment quality available worldwide. In particular the data on environment pollution in developing countries are more systematic The availability of long and multinational data sequence enables the application of econometric methodology to the analysis of the relationship between economic growth and environment quality. In the early 1990s, economists began empirical studies on environment indicators and economic factors. Researchers such as Grossman and Krueger (1991, 1995) and Shafik and Bandyopadhyay (1992, 1995) first established the inverted-U curve between environment pollution and per capita income, which is named Environmental Kuznets Curve (EKC). The main hypothesis of EKC is that environment quality will change for the worse first and then for the better over time with the growth of per capita income.

With the perfection and availability of data on environmental indicators, there are an increasing number of cross-country or single-country empirical studies on the relationship between environment quality and economic growth. The results of these studies are varied with several curves of different shapes, including inverted-U-shaped, U-shaped, N-shaped, inverted-N-shaped, and approximate linear curves (Panayotou, 2000). In terms of the selection of environment indicators, the main focus of studies in China is on the relationship between industrial pollution and economic growth with time series data or provincial panel data. The main focus of studies in other countries is on the relationship between air pollution and economic growth with multinational data.

Early studies on EKC are based on multinational cross-sectional data. Dasgupta et al. (1995) found that environment quality could be well-explained by per capita income, the extent of urbanization and industrialization, the safety of property rights and the efficiency of public administration. Wang (2000) established the effects of pollution tax system through a study on the cross-sectional data of three thousand 
plants in China in 1993. Torras and Boyce (1998) explored the link of income, income inequality, literacy, civil rights and liberty to pollution. Bimonte (2001) examined the relationship between the ratio of protected areas to national territory in European countries, per capita income and Gini coefficient.

Many scholars have obtained the inverted-U curve with cross-sectional and panel data. However some researchers argue that the relationship between environment quality and per capita income obtained with cross-country data may not be applied to a single country. Meanwhile the development of econometric methodology on time series data has prompted the wave of studies with time series data sequence. Egli (2002, 2005 ) analysed the link between environment quality and per capita income with an error-correction model and reached a negative conclusion for EKC hypothesis. Deacon and Norman (2006) confirmed the EKC hypothesis with a study on the connection between per capita income and the concentrations of sulphur dioxide, smoke and suspended particle matter (SPM) for 14 countries. Selden, Forrest \& Lockhart (1999) examined U.S. emissions of six air pollutants between 1970 and 1990, decomposing the observed changes into scale, composition, energy efficiency, energy mix, and other technique effects. Gergel et al. (2004) concluded economic prosperity cannot be expected to improve all aspects of the environment, but may be biased toward aspects that are ecologically reversible phenomena or of concern to human health. Bruvoll (2003) proposed that the changes in air pollution between 1980 and 1996 arise from economic growth, the scale and energy use of production. Panayotou, et al. (2000) related per capita $\mathrm{CO}_{2}$ to per capita income, population density, export trade and capital stock with the time series data of the UK and US.

Many Chinese researchers have studied the EKC hypothesis with time series data (Zhang, 1999; Zhao, 2005; Song et al., 2007; Chen et al., 2009; Peng, 2006; Ling et al., 2001). Their findings are inconclusive and sometimes contradictory. Zhang (1999) found that the relationship between environment quality and economic development shows some weak characteristics of the EKC hypothesis. Zhao (2005) related economic growth to environment indicators including wastewater discharge and waste gas emissions reaching contradictory conclusions for the EKC hypothesis. Song et al. (2007) found that the relationship between per capita income and $\mathrm{CO}_{2}$ emissions is an inverted-U curve. Chen et al. (2009) established simultaneous equations including pollution function and production function, concluding that the relationship between industrial sulphur dioxide emissions and economic growth confirms the EKC hypothesis. Peng (2006) argued that economic growth had led to the increase of environment pollution after an analysis with generalized impulse response functions. Ling et al. (2001) obtained an increasing pollution-income curve with a study on the link of per capita GDP to waste gas emissions, solid waste production, and sulphur dioxide in the Chinese city of Nanjing.

With the progress of econometric methodology, many scholars have also examined the relationship between economic growth and environment pollution with cross-sectional data. Ansuategi (2003) explored European economic growth and transboundary pollution with cross-sectional data. Markandya (2006) analysed the relationship between per capita GDP and sulphur emissions of 12 west European countries. Aldy (2004) testified the production-based and consumption-based EKC with the US interstate data on $\mathrm{CO}_{2}$ emissions. Mukherjee and Kathuria (2006) explored the relationship between rapid economic growth and environment quality in India. Mazzanti (2007) analysed the relationship between environment quality and per capita income in Italy. Martinez-Zarzoso and Bengochea-Morancho (2003) discussed the relationship between $\mathrm{CO}_{2}$ emissions and per capita income in Latin American countries. Paraskevopoulos (2009) testified the relationship between environment pollution and per capita income in the US and UK. Paudel and Schafer (2009) linked water pollution to social capital and per capita income with negative conclusions for EKC. Rupasingha et al. (2004) explored the relationship between the US county-level per capita income and toxic pollutants with spatial econometric analyses. Based on an analysis of China's provincial and regional data, Jiang, Lin, and Zhuang (2008) found that there was an inverted-U curve between per capita wastewater discharge, waste gas emissions and per capita income. Chen (2007) found that the shapes of pollution-income curves were varied with various industrial pollutants.

Although panel data provides more information, the impacts and feedback of economic growth on environment quality usually lag many years behind. This time lag can only be analysed through time series data. Therefore, in order to explore the interactions and feedback between environment quality and economic growth and measure the time lag between them, this paper builds several models on the basis of time series data analyses and carries out a comprehensive study on the relationship between industrial pollution and economic factors.

\section{Variable Selection and Data Preparation}

According to China Statistical Yearbooks from 1980 to 2008, Chinese environmental data collection started systematically from 1980. To ensure the length of data sequence, industrial waste gas emissions, industrial 
wastewater discharge, and industrial solid waste production are used as environment indicators. The data on industrial waste gas emissions covers from 1983 to 2008, and the data on other two indicators covers from 1980 to 2008. Per capita GDP calculated in the base year of 1980 is used as the indicator of economic growth, the data of which covers from 1980 to 2008 .

In order to avoid pseudo-regression problems, ADF unit root test is used to test the stability of the data sequence before the estimation of the model. The results of ADF unit root test show that the logarithms of all variables including per capita GDP, industrial wastewater discharge, industrial waste gas emissions and industrial solid waste production are all first-order difference stationary (the results of unit root test are omitted here, and the statistical software used in the paper is Eviews 6.0). Therefore Johansen co-integration test can be used, the results of which are listed in Table 1.

Table 1. The results of Johansen co-integration test on per capita GDP and environment indicators

\begin{tabular}{|c|c|c|c|c|c|c|}
\hline $\begin{array}{l}\text { Variables of } \\
\text { industrial } \\
\text { pollution } \\
\text { (logarithm) }\end{array}$ & $\begin{array}{l}\text { The lag } \\
\text { lengths of } \\
\text { VAR } \\
\text { models }\end{array}$ & Trace-statistics & $\begin{array}{c}\text { critical } \\
\text { value } \\
5 \%\end{array}$ & $\begin{array}{l}\text { Statistics of } \\
\text { maximum } \\
\text { eigen value }\end{array}$ & $\begin{array}{l}\text { critical } \\
\text { value } \\
5 \%\end{array}$ & $\begin{array}{l}\text { Existence of } \\
\text { Co-integration } \\
\text { relationship }\end{array}$ \\
\hline \multirow{2}{*}{$\begin{array}{l}\text { Industrial waste } \\
\text { gas emissions }\end{array}$} & \multirow{2}{*}{2} & 20.348 & 12.321 & 14.556 & 11.225 & \multirow{2}{*}{ Yes } \\
\hline & & 5.792 & 4.130 & 5.792 & 4.130 & \\
\hline \multirow{2}{*}{$\begin{array}{l}\text { Industrial waste } \\
\text { water discharge }\end{array}$} & \multirow{2}{*}{2} & 15.397 & 12.321 & 14.350 & 11.225 & \multirow{2}{*}{ Yes } \\
\hline & & 1.047 & 4.130 & 1.047 & 4.130 & \\
\hline \multirow{2}{*}{$\begin{array}{l}\text { Industrial solid } \\
\text { waste production }\end{array}$} & \multirow{2}{*}{2} & 20.033 & 12.321 & 16.897 & 11.225 & \multirow{2}{*}{ Yes } \\
\hline & & 3.136 & 4.130 & 3.136 & 4.130 & \\
\hline
\end{tabular}

Note: The selection of VAR lag length is determined by the rule of majority after calculating the separate lag length under LR, FPE, AIC, SC, and HQ. The critical value is given by Eviews 6.0.

The results of co-integration test show that there is co-integration relationship between the data sequences of the three types of industrial pollution and per capita GDP, which means that industrial pollution goes along with economic growth. Economic growth will inevitably have an impact on industrial pollution and there is stable co-integration relationship between environment quality and economic growth. Although in the short run the amount of industrial pollution sometimes deviates from its mean value due to the random disturbance of various economic and social factors, it will return to equilibrium over time. In addition, there is positive cointegration between the three types of industrial pollution and per capita GDP, which means that in the current stage of development the increase of per capita GDP has not reduced the amount of industrial pollution.

\section{Vector Autoregression Model}

\subsection{Vector Autoregression Model (VAR)}

The statistical nature of some data implies that there are real associations between variables. As such, a VAR model, which does not distinguish endogenous variables from exogenous variables, is built on these assumptions. Compared with simultaneous equations, VAR requires very little prior information with its focus on predicting the interrelated system of time series data. It is used to analyse the dynamic impact of impulse values (random error items) on the system, and hence it can be used to analyse the impacts of various factors on economic variables (Gao, 2009). Given these advantages, a VAR model is established with the first-order difference sequence of the logarithms of industrial waste gas emissions, industrial wastewater discharge, industrial solid waste production, and per capita GDP. There are many rules to determine the lag length of VAR models. In this part, the best lag length is determined by the rule of majority after calculating the separate lag length under the likelihood ratio (LR), final prediction error (FPE), Akaike information criterion (AIC), Schwarz criterion (SC), and Hannan-Qinn (HQ) criterion(Gao, 2009). The best lag length for the VAR model on industrial wastewater and per capita GDP is one while the lag length for the other three VAR models is two.

The VAR model on industrial waste gas $(i w g)$ emissions and per capita GDP $(g)$ obtained with OLS estimation is as follows: 


$$
\left(\begin{array}{c}
\Delta \ln i w g_{t} \\
\Delta \ln g_{t}
\end{array}\right)=\left(\begin{array}{c}
0.074 \\
0.058
\end{array}\right)+\left(\begin{array}{cc}
0.248 & 0.185 \\
-0.060 & 0.866
\end{array}\right)\left(\begin{array}{c}
\Delta \ln i w g_{t-1} \\
\Delta \ln g_{t-1}
\end{array}\right)+\left(\begin{array}{cc}
0.322 & -0.693 \\
0.035 & -0.556
\end{array}\right)\left(\begin{array}{c}
\Delta \ln i w g_{t-2} \\
\Delta \ln g_{t-2}
\end{array}\right)+\left(\begin{array}{c}
e_{1 t_{2}} \\
e_{2 t_{2}}
\end{array}\right)
$$

The VAR model on industrial wastewater (iw) discharge and per capita GDP is as follows:

$$
\left(\begin{array}{c}
\Delta \ln i w_{t} \\
\Delta \ln g_{t}
\end{array}\right)=\left(\begin{array}{c}
-0.026 \\
0.042
\end{array}\right)+\left(\begin{array}{cc}
-0.388 & 0.333 \\
-0.040 & 0.508
\end{array}\right)\left(\begin{array}{c}
\Delta \ln i w_{t-1} \\
\Delta \ln g_{t-1}
\end{array}\right)+\left(\begin{array}{c}
e_{1 t_{3}} \\
e_{2 t_{3}}
\end{array}\right)
$$

The VAR model on industrial solid waste production (isp) and per capita GDP is as follows:

$$
\left(\begin{array}{c}
\Delta \ln i s p_{t} \\
\Delta \ln g_{t}
\end{array}\right)=\left(\begin{array}{c}
0.006 \\
0.058
\end{array}\right)+\left(\begin{array}{cc}
-0.071 & 0.908 \\
0.047 & 0.832
\end{array}\right)\left(\begin{array}{c}
\Delta \ln i s p_{t-1} \\
\Delta \ln g_{t-1}
\end{array}\right)+\left(\begin{array}{cc}
0.187 & -0.333 \\
0.057 & -0.605
\end{array}\right)\left(\begin{array}{c}
\Delta \ln i s p_{t-2} \\
\Delta \ln g_{t-2}
\end{array}\right)+\left(\begin{array}{c}
e_{1 t_{4}} \\
e_{2 t_{4}}
\end{array}\right)
$$

The stability test on these VAR models shows that these models are stationary. The results of these models show that the fluctuation of waste gas emissions in the previous period will have a positive impact on the current period while wastewater discharge and solid waste production in the current period have negative impacts on the next period. The fluctuation of per capita GDP in the previous period will have positive impacts on all environment indicators of the current period, but it has negative impacts on environment indicators after two periods. This means that the increase of per capita GDP has lag effects on environment quality. Other than wastewater discharge, the changes of waste gas emissions and solid waste production on per capita GDP are positive, which shows that pollution is still an inevitable by-product of production and consumption in the sample period. China's economic growth is still driven by pollution-intensive industries.

\subsection{Structural Vector Autoregression Model (SVAR)}

The contemporaneous correlation matrix of the residuals in VAR models can be used to test whether there is contemporaneous correlation between the disturbance items. The correlation coefficient of the residuals of $\Delta \ln i w g$ and $\Delta \operatorname{lng}$ is 0.45 ; the coefficient of the residuals of $\Delta \ln i w$ and $\Delta \ln g$ is 0.12 ; the coefficient of the residuals of $\Delta \ln i s p$ and $\Delta \operatorname{lng}$ is -0.19 . These results show that there is contemporaneous correlation between environment indicators and per capita GDP. The error items $\left(\mathrm{e}_{1 t}, \mathrm{e}_{2 t}\right)^{\mathrm{T}}$ in the VAR models can not be observed, therefore the contemporaneous correlation between them can not be depicted. In order to identify the hidden contemporaneous correlation in the disturbances of VAR models, SVAR models are necessary.

The matrix equation of SVAR with two variables and one lag length (Take the equation between industrial wastewater discharge and per capita GDP as an example) can be written as:

$$
\left(\begin{array}{cc}
1 & -c_{12} \\
-c_{21} & 1
\end{array}\right)\left(\begin{array}{l}
\Delta \ln E_{t} \\
\Delta \ln g_{t}
\end{array}\right)=\left(\begin{array}{l}
\alpha_{10} \\
\alpha_{20}
\end{array}\right)+\left(\begin{array}{ll}
\alpha_{11} & \alpha_{12} \\
\alpha_{21} & \alpha_{22}
\end{array}\right)\left(\begin{array}{l}
\Delta \ln E_{t-1} \\
\Delta \ln g_{t-1}
\end{array}\right)+\left(\begin{array}{l}
u_{1 t} \\
u_{2 t}
\end{array}\right)
$$

Where $E_{t}$ is environment variable. The variables in the model are all stationary random processes; the random error items are white noise sequence; $u_{1 t}$ and $u_{2 t}$ are not correlated. Thus the interplay and feedback between variables are introduced into the economic model, of which $c_{12}$ means the immediate effect of the percentage changes of $\Delta \ln g_{t}$ on $\Delta \ln E_{t} ; \quad \alpha_{12}$ is the lag effect of the percentage changes of $\Delta \ln g_{t-1}$ on $\Delta \ln E_{t}$.

The matrix equation of the simplified and structural disturbances of the VAR model, i.e. SVAR model, can be written as:

$$
\left(\begin{array}{ll}
1 & 0 \\
0 & 1
\end{array}\right)\left(\begin{array}{l}
e_{1 t} \\
e_{2 t}
\end{array}\right)=\left(\begin{array}{cc}
1 & a_{12} \\
a_{21} & 1
\end{array}\right)\left(\begin{array}{l}
u_{1 t} \\
u_{2 t}
\end{array}\right)
$$

Where $\left(\begin{array}{l}e_{1 t} \\ e_{2 t}\end{array}\right)$ is the disturbance of the VAR model, $u_{1 t}$ and $u_{2 t}$ are the structural impulses on $\Delta \ln i w g$, 
$\Delta \ln i w, \Delta \ln i s p$ and $\Delta \ln g$, simplified disturbances $\left(\begin{array}{l}e_{1 t} \\ e_{2 t}\end{array}\right)$ are the linear combinations of the structural disturbances $\left(\begin{array}{l}u_{1 t} \\ u_{2 t}\end{array}\right)$, which represents a type of complex impulse.

Because there are 2 endogenous variables in the model, at least 5 constraint conditions are required to satisfy the identifiable conditions of the SVAR model. There are 6 constraint conditions in Equation (5), therefore the identifiable condition is satisfied and full information maximum likelihood can be used to estimate unknown parameters. The estimation results of the linear combinations of the simplified disturbances and structural disturbances are as follows:

$$
\begin{aligned}
& \left(\begin{array}{ll}
1 & 0 \\
0 & 1
\end{array}\right)\left(\begin{array}{l}
e_{1 t_{2}} \\
e_{2 t_{2}}
\end{array}\right)=\left(\begin{array}{cc}
1 & 1.797 \\
0.522 & 1
\end{array}\right)\left(\begin{array}{l}
u_{1 t_{2}} \\
u_{2 t_{2}}
\end{array}\right) \\
& \left(\begin{array}{ll}
1 & 0 \\
0 & 1
\end{array}\right)\left(\begin{array}{l}
e_{1 t_{3}} \\
e_{2 t_{3}}
\end{array}\right)=\left(\begin{array}{cc}
1 & 1.512 \\
0.610 & 1
\end{array}\right)\left(\begin{array}{l}
u_{1 t_{3}} \\
u_{2 t_{3}}
\end{array}\right) \\
& \left(\begin{array}{ll}
1 & 0 \\
0 & 1
\end{array}\right)\left(\begin{array}{l}
e_{1 t_{4}} \\
e_{2 t_{4}}
\end{array}\right)=\left(\begin{array}{cc}
1 & 1.639 \\
0.549 & 1
\end{array}\right)\left(\begin{array}{l}
u_{1 t_{4}} \\
u_{2 t_{4}}
\end{array}\right)
\end{aligned}
$$

The corresponding SVAR models are written as:

$$
\begin{aligned}
& \left(\begin{array}{c}
\Delta \ln i w g_{t} \\
\Delta \ln g_{t}
\end{array}\right)=\left(\begin{array}{c}
-0.008 \\
0.047
\end{array}\right)+\left(\begin{array}{cc}
0 & 1.416 \\
0.143 & 0
\end{array}\right)\left(\begin{array}{c}
\Delta \ln i w g_{t} \\
\Delta \ln g_{t}
\end{array}\right)+\left(\begin{array}{cc}
0.333 & -1.041 \\
-0.095 & 0.840
\end{array}\right)\left(\begin{array}{c}
\Delta \ln i w g_{t-1} \\
\Delta \ln g_{t-1}
\end{array}\right) \\
& +\left(\begin{array}{cc}
0.272 & 0.094 \\
-0.011 & -0.457
\end{array}\right)\left(\begin{array}{c}
\Delta \ln i w g_{t-2} \\
\Delta \ln g_{t-2}
\end{array}\right)+\left(\begin{array}{l}
u_{1 t_{2}} \\
u_{2 t_{2}}
\end{array}\right) \\
& \left(\begin{array}{c}
\Delta \ln i w_{t} \\
\Delta \ln g_{t}
\end{array}\right)=\left(\begin{array}{c}
-0.039 \\
0.043
\end{array}\right)+\left(\begin{array}{cc}
0 & 0.322 \\
0.044 & 0
\end{array}\right)\left(\begin{array}{c}
\Delta \ln i w_{t} \\
\Delta \ln g_{t}
\end{array}\right)+\left(\begin{array}{cc}
-0.375 & 0.169 \\
-0.023 & 0.494
\end{array}\right)\left(\begin{array}{c}
\Delta \ln i w_{t-1} \\
\Delta \ln g_{t-1}
\end{array}\right)+\left(\begin{array}{l}
u_{1 t_{3}} \\
u_{2 t_{3}}
\end{array}\right) \\
& \left(\begin{array}{c}
\Delta \ln i s p_{t} \\
\Delta \ln g_{t}
\end{array}\right)=\left(\begin{array}{c}
0.049 \\
0.059
\end{array}\right)+\left(\begin{array}{cc}
0 & -0.735 \\
-0.047 & 0
\end{array}\right)\left(\begin{array}{c}
\Delta \ln i s p_{t} \\
\Delta \ln g_{t}
\end{array}\right)+\left(\begin{array}{cc}
-0.037 & 1.520 \\
0.044 & 0.875
\end{array}\right)\left(\begin{array}{c}
\Delta \ln i s p_{t-1} \\
\Delta \ln g_{t-1}
\end{array}\right) \\
& +\left(\begin{array}{ll}
0.229 & -0.778 \\
0.066 & -0.620
\end{array}\right)\left(\begin{array}{c}
\Delta \ln i s p_{t-2} \\
\Delta \ln g_{t-2}
\end{array}\right)+\left(\begin{array}{l}
u_{1 t_{4}} \\
u_{2 t_{4}}
\end{array}\right)
\end{aligned}
$$

From the models it can be seen that the current per capita GDP growth rate elasticity of the current industrial waste gas emission growth rate is 1.416 while the reverse is 0.143 ; the per capita GDP growth rate elasticity coefficients of industrial wastewater discharge and solid waste production growth rate are 0.322 and -0.735 . These results show that the increase of income growth rate will help slow down the growth of solid waste production, but will greatly speed up the growth rate of industrial waste gas. Therefore the fluctuation of economic growth rate will have different impacts on different environment indicators and even have contradictory effects on different types of pollutants. As a result, the implications for policy making are that the effects of economic growth on different pollutions should be fully considered before making any rational decisions. 


\section{Analyses of Generalized Impulse Response Functions (GIRF)}

In reality, VAR models do not have much solid theoretical basis. Therefore the methodology of generalized impulse response function is developed to carry out meaningful analyses on VAR models. The results of GIRF analysis on the impulse response of three types of industrial pollution to per capita GDP are depicted in Figures 1, 2 , and 3 respectively. The horizontal axis is the years of lag periods; the vertical axis is the fluctuations of the three types of industrial pollutions: the solid lines represent GIRF; dotted lines represent the deviation zone with a width of double standard deviations. Given the size of the sample, the period of impulse response is set at 10 years. From these figures it can be seen that the responses of the growth rate of three types of industrial pollution to positive impulses of per capita GDP are very different.

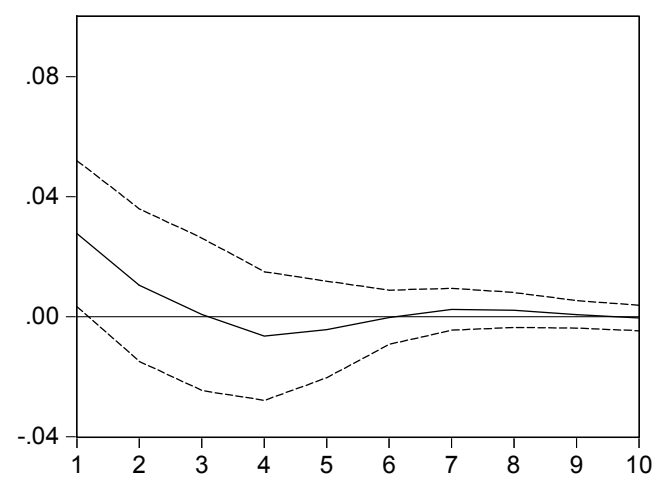

Figure 1. Response of industrial waste gas growth rate to per capita GDP growth rate

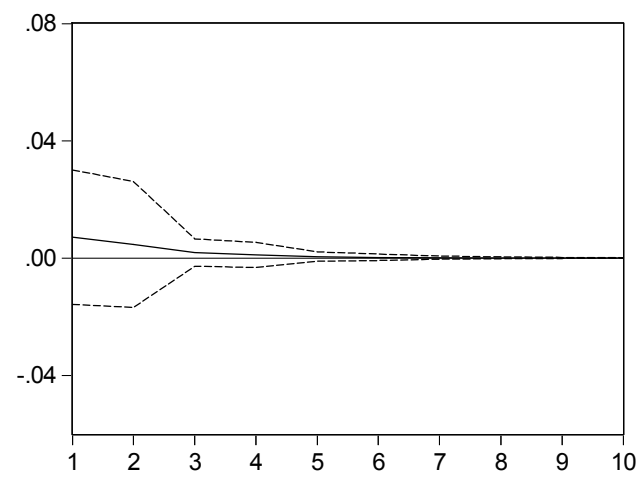

Figure 2. Response of industrial wastewater growth rate to per capita GDP growth rate

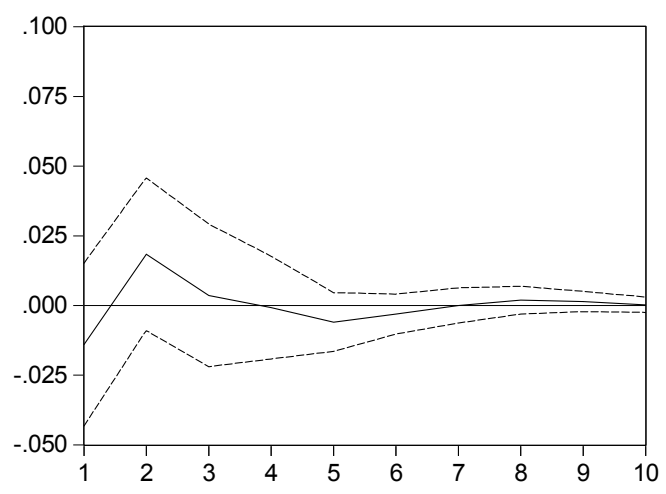

Figure 3. Response of industrial solid waste growth rate to per capita GDP growth rate

1) The response of industrial waste gas growth rate to per capita GDP growth rate. The positive impulse of per capita GDP growth rate has positive effects on industrial waste gas growth rate in the first period, but the effects diminish gradually and turn negative in the third period. The negative effects reach the peak in the fourth period. After the sixth period the effects turn positive again but nearly go to zero gradually. The cumulative impulse response value of the first five periods is -0.0043 . The cumulative impulse response value of the total 10 periods is -0.0005 .

2) The response of industrial wastewater growth rate to per capita GDP growth rate. The positive impulse of per capita GDP growth rate has the highest positive effects on industrial wastewater growth rate in the first period; the effects then diminish gradually and nearly go to zero after the fifth period, which shows that the effects of per capita GDP growth rate on industrial wastewater growth rate last for about five years. The cumulative impulse response value of the first five periods is 0.01515 . The cumulative impulse response value of the total 10 periods is 0.01563 . The two values are very close, but they are both positive and therefore the fluctuation of per capita GDP growth rate has dramatic effects on the growth rate of industrial wastewater.

3) The response of industrial solid waste growth rate to per capita GDP growth rate. In contrast with the two 
previous environment variables, the positive impulse of per capita GDP growth rate has negative effects on industrial solid waste production in the first period. But the effects turn positive in the second period and then drop quickly. In the fourth period the effects turn negative again which means that the effects are fluctuant from one period to another. The cumulative impulse response values of the first five and the total ten periods are very closely around 0.001 . It can be seen that the increase of per capita growth rate will increase the growth rate of industrial solid waste by about $0.1 \%$ in total 10 periods.

The analyses above show that the responses of the three indicators of environment quality to per capita GDP growth rate are mostly fluctuant. Only the response of industrial wastewater growth rate is always positive. However generally speaking, the positive impulse of per capita GDP growth rate will increase pollution and then aggravate the deterioration of environment quality, which is consistent with previous conclusions, i.e. the increase of per capita income still have negative impacts on environment quality in the current stage (Peng \& Bao, 2006; Zhang \& Ma, 2005).

Economic growth increases environment pollution. Meanwhile due to the better public awareness of environment protection, Chinese government attaches greater importance to pollution reduction and environment restoration. However the public holds divergent opinions about the formulation and implementation of environment regulations and some people worry that stringent environment policies will slow down economic growth (Su et al., 2007; Zhang \& Ma, 2005). Therefore we are more concerned with the effects of pollution reduction on economic growth. Figures 4, 5, and 6 show the generalized impulse response of per capita GDP growth to industrial pollution reduction. The horizontal axis stands for the years of lag periods of the environment impulses; the vertical axis is the changes of per capita GDP growth rate. Solid lines represent GIRF (generalized impulse response function); dotted lines represent the deviation zone with a width of double standard deviations. The period of impulse response is set at 10 years. From these figures it can be seen that the responses of per capita GDP growth rate to negative impulses of industrial pollution are mostly fluctuant.

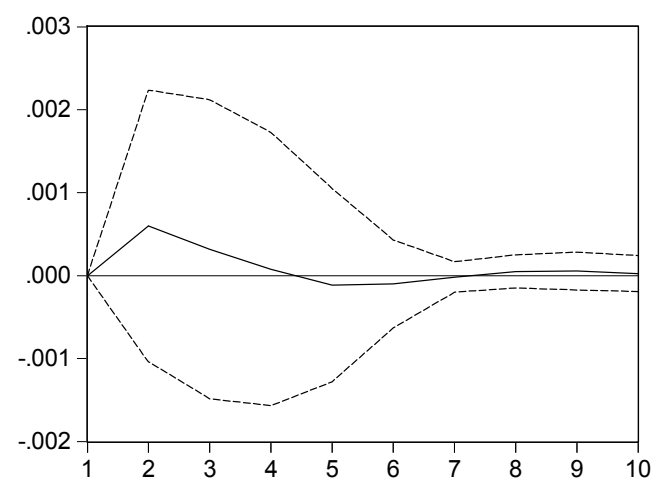

Figure 4. Response of per capita GDP growth rate to negative impulses of industrial waste gas emissions

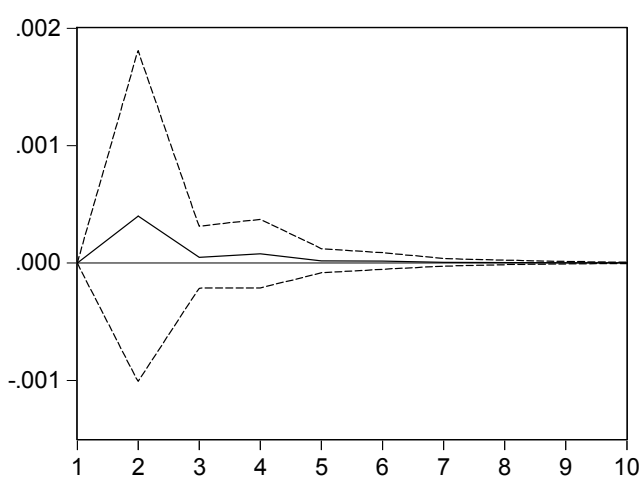

Figure 5. Response of per capita GDP growth rate to negative impulses of industrial wastewater discharge

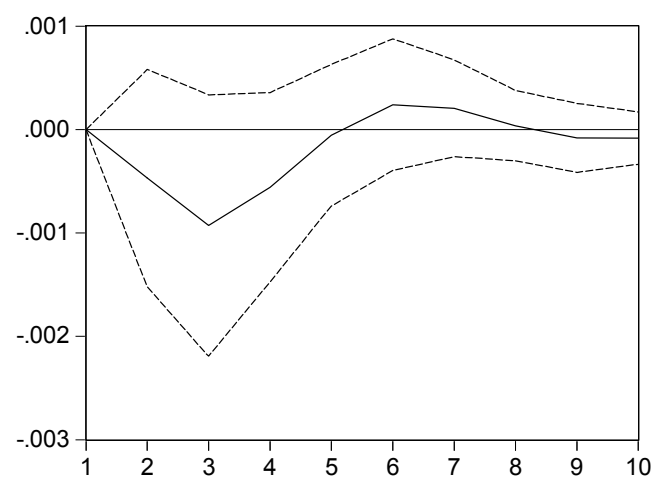

Figure 6. Response of per capita GDP growth rate to negative impulses of industrial solid waste production 
4) The response of per capita GDP growth rate to reduction of industrial waste gas emissions. The response of per capita GDP growth rate to negative impulse of industrial waste gas emissions is positive and reaches the peak in the second period. Then it drops quickly and turns negative after the fifth period, but gradually diminishes. The cumulative response value is always positive, which means that the slowdown of industrial waste gas emissions will not decrease economic growth and instead will promote economic growth.

5) The response of per capita GDP growth rate to decrease of industrial wastewater discharge growth rate. The response of per capita GDP growth rate to reduction of industrial wastewater discharge is always positive and reaches the peak in the second period, but it gradually goes to zero after the third period, which means that the decrease of industrial wastewater growth rate through policies and regulations has favourable effects on economic growth, but the effects do not last very long.

6) The response of per capita GDP growth rate to decrease of industrial solid waste growth rate. The response of economic growth rate to industrial solid waste growth rate is similar to that of energy consumption, which is fluctuant between negative effects and positive effects, of which the negative effects reach its peak in the third period. The effects will turn positive again after the fifth period and then gradually diminish.

The analyses above show that controlling the amount of industrial pollution will not slow down economic growth but accelerate the growth of per capita GDP. These effects can usually be seen within two years but they will diminish very quickly. Therefore it is unnecessary to worry about the negative effects of environment regulations on economic growth.

\section{Variance Decomposition Analyses}

Variance decomposition examines the contribution of every structural impulse to the changes of endogenous variables so as to study the relative importance of different structural impulses. Therefore, in contrast with impulse response function which describes the impacts of one endogenous variable on other endogenous variables in a VAR model, variance decomposition provides information on the relative importance of each random disturbance affecting the variables in the model and quantifies the interplay between variables. Based on the previous SVAR model, the results of variance decomposition of industrial pollution and per capita GDP are listed in Table 2.

Table 2. The results of variance decomposition of industrial pollution and per capita GDP

\begin{tabular}{|c|c|c|c|c|c|c|}
\hline period & $\begin{array}{l}\text { Percentage of } \\
\text { per capita } \\
\text { GDP growth } \\
\text { rate due to the } \\
\text { impulse of } \\
\text { waste gas } \\
\text { emission } \\
\text { growth rate } \\
(\%)\end{array}$ & $\begin{array}{c}\text { Percentage of } \\
\text { per capita GDP } \\
\text { growth rate } \\
\text { due to the } \\
\text { impulse of } \\
\text { wastewater } \\
\text { discharge } \\
\text { growth rate } \\
(\%)\end{array}$ & $\begin{array}{c}\text { Percentage of } \\
\text { per capita } \\
\text { GDP growth } \\
\text { rate due to the } \\
\text { impulse of } \\
\text { solid waste } \\
\text { production } \\
\text { growth rate } \\
(\%)\end{array}$ & $\begin{array}{l}\text { Percentage of } \\
\text { waste gas } \\
\text { emission } \\
\text { growth rate } \\
\text { due to the } \\
\text { impulse of per } \\
\text { capita GDP } \\
\text { growth rate } \\
(\%)\end{array}$ & $\begin{array}{l}\text { Percentage of } \\
\text { wastewater } \\
\text { discharge } \\
\text { growth rate } \\
\text { due to the } \\
\text { impulse of per } \\
\text { capita GDP } \\
\text { growth rate } \\
(\%)\end{array}$ & $\begin{array}{l}\text { Percentage of } \\
\text { solid waste } \\
\text { production } \\
\text { growth rate } \\
\text { due to the } \\
\text { impulse of per } \\
\text { capita GDP } \\
\text { growth rate } \\
(\%)\end{array}$ \\
\hline 1 & 21.392 & 27.141 & 23.160 & 76.350 & 69.572 & 72.877 \\
\hline 2 & 21.276 & 27.067 & 23.312 & 76.423 & 69.449 & 73.695 \\
\hline 3 & 21.267 & 27.066 & 23.397 & 76.363 & 69.466 & 73.849 \\
\hline 4 & 21.279 & 27.063 & 23.349 & 76.452 & 69.464 & 73.848 \\
\hline 5 & 21.277 & 27.063 & 23.334 & 76.491 & 69.465 & 73.885 \\
\hline 6 & 21.276 & 27.063 & 23.342 & 76.486 & 69.465 & 73.908 \\
\hline 7 & 21.276 & 27.063 & 23.338 & 76.486 & 69.465 & 73.909 \\
\hline 8 & 21.276 & 27.063 & 23.335 & 76.488 & 69.465 & 73.913 \\
\hline 9 & 21.276 & 27.063 & 23.336 & 76.487 & 69.465 & 73.917 \\
\hline
\end{tabular}

The results of variance decomposition show that the percentage of per capita GDP growth due to the impulse of industrial pollution is between $20 \%$ and $30 \%$ excluding the contribution of per capita GDP growth itself. That is to say, the contribution of pollution indicators to the variance decomposition of per capita GDP is relatively small. In contrast, the contribution of per capita GDP to the variance decomposition of industrial pollution is 
very significant and per capita GDP is the main variable to explain the forecasting mean square error of the pollution variable. The results reflect the current situation of the relationship between environment quality and per capita income in China. This is, rapid economic growth goes along with the increase of industrial pollution, exerting great pressure on ecological environment. Meanwhile the damages of industrial pollution to environment quality have not been fully embodied in the slowdown of economic growth.

\section{Conclusions}

This paper uses econometric analyses of time-series data between 1980 and 2008, examines the long-term dynamic equilibrium and interplay between environment quality and per capita income in China, and obtains the following points:

1) There is cointegration between economic growth and environment pollution. Economic growth will have an impact on industrial pollution production; on the other hand the increase of industrial pollution will have a negative impact on economic growth. Therefore, the constraints of natural resources and environment can not be ignored. When discussing the relationship between environment quality and economic growth, the changes of environment quality brought about by economic growth should not only be considered, but the feedback of environment quality on economic growth should also be considered.

2) The increase of per capita GDP has evident lag effects on environment quality. Other than wastewater discharge, the changes of waste gas emissions and solid waste production both have positive effects on per capita GDP, which means that in the sample period environment quality is still an inevitable by product of economic activities and China's industrial structure is still dominated by resource-intensive and pollution-intensive industries. In terms of structural changes, the increase of per capita GDP growth rate is conducive to the decrease of industrial solid waste growth rate, but it helps increase the growth rate of waste gas emissions and wastewater discharge. Therefore the changes of economic growth rate will have different effects on different environment problems, and will even have contradictory effects on different types of pollutants. As a result, the implications for policy making are that the effects of economic growth on different pollutions should be fully considered before making any rational decisions.

3) The simulated structure of GIRF shows that the responses of environment quality indicators to the impulse of per capita growth rate are mostly fluctuant. Only the response of industrial wastewater discharge growth rate is always positive. In general, the positive impulse of per capita GDP growth rate will increase pollution and aggravate the deterioration of environment quality. Economic growth increases environment pollution, meanwhile the growing public awareness of environment protection has forced Chinese government to pay attention to pollution control and reduction. Environment regulations will not slow down economic growth, but will speed up per capita GDP growth for a short period.

4) The results of variance decomposition show that the contribution of pollution indicators to the variance decomposition of per capita GDP is relatively small. In contrast, the contribution of per capita GDP to the variance decomposition of industrial pollution is very significant and the constraints of environment pollution on economic growth have not been fully embodied. This could be possibly explained by the following reasons. First of all, China's economic growth is still driven by the expansion of conventional factors of production such as capital and labor. In particular, the fundamental driving force behind China's economic growth is foreign trade and the accumulation of physical capital. Therefore, in relation to these factors of economic growth, the change of environment quality has very little effect on economic growth. Secondly, the inverted-U curve between environment quality and per capita income is partially determined by consumers' environment-income elasticity. Environment quality is a normal good, therefore with the growing income the public will be more aware of environment issues and environment quality becomes more significant, which will encourage the public to promote the formulation and implementation of environment regulations and policies. However, in the current stage consumers' preference for better environment is still very low in the utility function, and only when there is an environment accident, will the public pay more attention to environment problems. Thirdly, China has not established an effective market mechanism for resources utilization, energy consumption and internalization of pollution externalities, and there is no clear-cut definition for the property rights of pollution, which means at the microeconomic level firms do not have to take full responsibility for the social cost of their pollution. The damages of environment pollution to economic development are not fully compensated. Finally, secondary industries especially pollution-intensive industries still dominate China's economic structure. Meanwhile the effects of ecological degradation and environment pollution on economic growth could be entirely seen in the short run. Therefore in the sample period of this study the damages of environment pollution to economic development are not completely embodied. These elements limit the feedback of environment quality to 
economic growth, which leads to the public's negligence of the irreversibility of ecological degradation and undermines future economic and social development.

In conclusion, economic growth has different effects on different environment issues. Environment pollution has lag effects on economic growth. In particular the constraints of environment pollution on economic growth can only be seen in the long run. Therefore we should formulate effective economic and administrative regulations and policies to tackle different environment problems so as to control environment pollution effectively. In addition, the externalities of environment problems should be internalized and effective market mechanism for resources and pollution trading should be established. Meanwhile the environment awareness of the public should be raised and the public's appeal for better environment should be able to be expressed freely. Eventually at the microeconomic level environment concerns will have effects on firms' investment decisions, production and the consumption structure of the public.

\section{References}

Aldy, J. (2004). An Environmental Kuznets Curve analysis of U.S. state-level carbon dioxide emissions. Repsol YPF-Harvard Kennedy School Fellows 2003-2004 Research Papers. Cambridge, MA April 2005, 149-174. Retrieved from http://www.hks.harvard.edu/m-rcbg/repsol_ypf-ksg_fellows/03-04_research_papers.pdf

Ansuategi, A. (2003). Economic growth and transboundary pollution in Europe: an empirical analysis. Environmental and Resource Economics, 26(2), 305-328. http://dx.doi.org/ 10.1023/A:1026387431794

Bimonte, S. (2001). Model of growth and environmental quality: new evidence of the Environmental Kuznets Curve. Università degli Studi di Siena, no. 321. Retrieved from https://www.cleis.unisi.it/dipartimento/files/321\%5B1\%5D.pdf

Bruvoll, A., \& Medin, H. (2003). Factors behind the Environmental Kuznets Curve - a decomposition of the changes in air pollution. Environmental and Resource Economics, 24(1), 27-48. http://dx.doi.org/10.1023/A:1022881928158

Cao, G. (2006). The relationship between economic growth and environment pollution in China. Journal of population, resources and environment, 16(1), 25-29. (in Chinese)

Chen, H., \& Chen, Q. (2009). Economic growth, foreign trade and environment pollution: an estimation of simultaneous equations. Journal of Industrial Economics, 40(3). 29-34. (in Chinese)

Chen, W. (2007). Economic growth and the environment in China: an empirical test of the Environmental Kuznets Curve using provincial panel data. Annual Conference on Development and Change, Cape Town, 2007.

from http://www.policyinnovations.org/ideas/policy_library/data/01447/_res/id=sa_File1/paper.pdf

Dasgupta, S., \& Mody, A. (1995). Environmental regulation and development: a cross-country empirical analysis. The World Bank Policy Research Working paper, 1448. Retrieved from www.amody.com/pdf/environment_indicators.pdf

Deacon, R., \& Norman, C. (2006). Does the Environmental Kuznets Curve describe how individual countries behave. Land Economics, 82(2), 291-315. http://dx.doi.org/10.3368/le.82.2.291

Egli, H. (2002). Are cross-country studies of the Environmental Kuznets Curve misleading? New evidence from time series data for Germany, FEEM Working Paper, No. 25. Retrieved from http://www.feem.it/userfiles/attach/Publication/NDL2002/NDL2002-025.pdf

Egli, H. (2005). The Environmental Kuznets Curve: theory and evidence, Dissertation, Zurich University.

Gao, T. (2009). Econometric analysis and modeling---a guide to Eviews with examples $\left(2^{\text {nd }}\right.$ ed.). Beijing: Tsinghua University Press. (in Chinese)

Gergel, S., Bennett, E., Greenfield, B., King, S., Overdevest, C., \& Stumborg, B. (2004). A test of the Environmental Kuznets Curve using long-term watershed inputs. Ecological Applications, 14(2), 555-570. http://dx.doi.org/10.1890/02-5381

Grossman, G., \& Krueger, A. (1991). Environmental impacts of a North American Free Trade Agreement. NBER Working paper, No. 3914. Retrieved from www.nber.org/papers/w3914.pdf

Grossman, G., \& Krueger, A. (1995). Economic growth and the environment. The Quarterly Journal of Economics, 110(2), 353-377. Retrieved from http://www.nber.org/papers/w4634.pdf

Jiang, Y., Lin, T., \& Zhuang, J. (2008). Environmental Kuznets Curves in the People's Republic of China: 
turning points and regional differences, Asian Development Bank. Economics Working Paper Series, No. 141. Retrieved from http://www.adb.org/sites/default/files/pub/2008/Economics-WP141.pdf

Ling, H., Wang, W., \& Liu, T. (2001). A statistical study on the relationship between urban economic development and environment pollution---a case study of Nanjing. Journal of Statistics Research, 10, 46-52. (in Chinese)

Markandya, A., Golub, A., \& Pedroso-Galinato, S., (2006). Empirical analysis of national income and $\mathrm{SO}_{2}$ emissions in selected European countries. Environmental \& Resource Economics, 35, 221-257. http://dx.doi.org/10.1007/s10640-006-9014-2

Martinez-Zarzoso, I., \& Bengochea-Morancho, A. (2003). Testing for an Environmental Kuznets Curve in Latin-American countries. Revista de Análisis Económico, 18(1), 3-26. Retrieved from http://www.rae-ear.org/index.php/rae/article/viewFile/22/44

Mazzanti, M., Montini, A., \& Zoboli, R. (2007). Economic dynamics, emission trends and the EKC hypothesis: new evidence using NAMEA and provincial panel data for Italy. FEEM working paper No.24, 2007. Retrieved from http://www.feem.it/userfiles/attach/Publication/NDL2007/NDL2007-040.pdf

Mukherjee, S., \& Kathuria, V. (2006). Is economic growth sustainable? Environmental quality of Indian states post 1991, Madras School of Economics, Working paper, 2006/6. Retrieved from http://mpra.ub.uni-muenchen.de/6473/1/MPRA_paper_6473.pdf

Panayotou, T. (2000). Economic growth and the environment, Center for International Development at Harvard University. Working Paper, $\quad$ No. $56 . \quad$ Retrieved from http://www.hks.harvard.edu/var/ezp_site/storage/fckeditor/file/pdfs/centers-programs/centers/cid/publicatio $\mathrm{ns} /$ faculty/wp/056.pdf

Panayotou, T., Peterson, A., \& Sachs, J. (2000). Is the Environmental Kuznets Curve driven by structural change? what extended time series may imply for developing countries. Consulting Assistance on Economic Reform

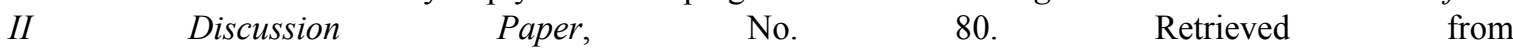
http://www.earth.columbia.edu/sitefiles/file/about/director/pubs/paper80.pdf

Paraskevopoulos, D. (2009). An empirical analysis of the Environmental Kuznets Curve hypothesis over two centuries: evidence from the UK and US, University of Macedonia Thessaloniki. Master Thesis. Retrieved from http://dspace.lib.uom.gr/bitstream/2159/13512/1/ParaskevopoulosMsc2009.pdf

Paudel, K., \& Schafer, M. (2009). The Environmental Kuznets Curve under a new framework: the role of social capital in water pollution. Environmental \& Resource Economics, 42, 265-278. http://dx.doi.org/ $10.1007 / \mathrm{s} 10640-008-9215-\mathrm{y}$

Peng, S., \& Bao, Q. (2006). China's economic growth and environment pollution---an empirical study based on generalized response function. China Industrial Economics, 5(5), 15-23. (in Chinese)

Rupasingha, A., Goetz, S., Debertin, D., \& Pagoulatos, A. (2004). The environmental Kuznets curve for US counties: A spatial econometric analysis with extensions. Papers Reg. Sci., 83(2), 407-424, http://dx.doi.org/10.1007/s10110-004-0199-x

Selden, T., Forrest, A., \& Lockhart, J. (1999). Analyzing the reductions in U.S. air pollution emissions: 1970 to 1990. Land Economics, 75(1), 1-21. Retrieved from http://www.jstor.org/discover/10.2307/3146990?uid=3737800\&uid=2\&uid=4\&sid=21101118574717

Shafik, N. (1994). Economic development and environmental quality: an econometric analysis. Oxford Economic Papers, 46, Special Issue on Environmental Economics, Oct., 757-773. Retrieved from http:/www.jstor.org/discover/10.2307/2663498?uid=3737800\&uid=2129\&uid=2\&uid=70\&uid=4\&sid=211 01118574717

Shafik, N., \& Bandyopadhyay, S. (1992). Economic growth and environmental quality: Time Series and Cross-country Evidence. Background Paper for World Development Report. Retrieved from http://www-wds.worldbank.org/servlet/WDSContentServer/WDSP/IB/1992/06/01/000009265_3961003013 329/Rendered/PDF/multi_page.pdf

Song, T., Zheng, T., \& Tong, L. (2007). A theoretical analysis and econometric test on the correlation between economic growth and environment pollution. Journal of Geographical Science, 27(2), 156-162. (in Chinese)

Su, W., \& Liu, J. (2007). A study on the relationship between economic growth and environment pollution in 
Jilin Province. Resources and Environment of Arid Zones, 21(2), 37-41. (in Chinese)

Torras, M., \& Boyce, J., (1998). Income, inequality, and pollution: a reassessment of the environmental Kuznets Curve. Ecological Economics, 25, 147-160. http://dx.doi.org/10.1016/S0921-8009(97)00177-8

Wang, H., \& Wheeler, D. (2000). Endogenous enforcement and effectiveness of China's pollution levy system. the World Bank Development Research Group Working Paper, 2336. Retrieved from http://elibrary.worldbank.org/docserver/download/2336.pdf

Zhang, P., \& Ma, X. (2005). Research On The Relationship of China Economy Development And Circumstance Pollution. Journal of Hunan University of Science and Engineering, 26(5), 264-268. (in Chinese)

Zhang, X. (1999). A general evaluation on China's environment policy. Journal of China Social Sciences, 45(3), 88-99. (in Chinese)

Zhao, X. (2005). An empirical test of Environment Kuznets Curve in China. Nankai Economic Studies, 20(3), 48-54. (in Chinese) 